\title{
Extreme reduction in nutritional value of a key forage fish during the Pacific marine heatwave of 2014-2016
}

\author{
Vanessa R. von Biela ${ }^{1, *}$, Mayumi L. Arimitsu ${ }^{2}$, John F. Piatt ${ }^{1}$, Brielle Heflin ${ }^{2}$, \\ Sarah K. Schoen ${ }^{1}$, Jannelle L. Trowbridge ${ }^{1,3}$, Chelsea M. Clawson ${ }^{1,4}$ \\ ${ }^{1}$ US Geological Survey, Alaska Science Center, 4210 University Drive, Anchorage, Alaska 99508, USA \\ ${ }^{2}$ US Geological Survey, Alaska Science Center, 250 Egan Dr., Juneau, Alaska 99801, USA \\ ${ }^{3}$ University of Alaska Anchorage, Alaska Native Science \& Engineering Program, 3211 Providence Drive, Anchorage, \\ Alaska 99508, USA \\ ${ }^{4}$ Alaska Sea Grant Marine Advisory Program, 1007 W $3^{\text {rd }}$ Avenue, Suite 100, Anchorage, Alaska 99501, USA
}

\begin{abstract}
Pacific sand lance Ammodytes personatus are a key forage fish in the North Pacific for many species of salmon, groundfish, seabirds, and marine mammals and have historically been important to predators in relatively warm years. However, extreme declines in the nutritional value of sand lance in Prince William Sound, Alaska, USA, during 2012-2016 indicate that energy transfer from lower trophic levels to predators via sand lance may have been disrupted during the North Pacific marine heatwave in 2015 and 2016. Nutritional value (length, energy density, and whole-body energy) was measured in age- 0 and age- 1 sand lance collected during July in cool (2012-2013) and increasingly warm (2014-2016) years. The value of age-0 fish was relatively stable, with only minor differences among years for length and whole-body energy. By contrast, the value of age-1 fish significantly declined in 2015, and by 2016 they were $38 \%$ shorter and $13 \%$ lower in energy density compared to cooler years. This contributed to significant declines in whole-body energy of $44 \%$ in 2015 and $89 \%$ in 2016 compared to cooler years (2012-2014). The 2015 sand lance cohort experienced little growth or lipid accumulation from July 2015 at age-0 to July 2016 at age-1. This effective disruption of energy flow through pelagic food webs probably contributed to population declines and/or breeding failures observed among several predators in the Gulf of Alaska and suggests that tipping points were reached during the heatwave.
\end{abstract}

KEY WORDS: Pacific sand lance · Ammodytes personatus · 'The Blob' · Gulf of Alaska · Body condition · Energy density

\section{INTRODUCTION}

Marine heatwaves (MHWs), such as one that persisted in the North Pacific Ocean from October 2013 to June 2016 (Hu et al. 2017) (and was dubbed 'the Blob'), are extreme ocean warming events that may result in severe impacts on marine ecosystems ( $\mathrm{Di}$ Lorenzo \& Mantua 2016, Peterson et al. 2016, Oliver et al. 2018, Walsh et al. 2018). The Pacific MHW cul-

*Corresponding author: vvonbiela@usgs.gov minated in record-breaking heat content anomalies in 2016 for the Gulf of Alaska (Walsh et al. 2018). Ocean warmth was intensified by a strong El Niño event and strong positive sea level pressure anomalies that suppressed heat loss to the atmosphere (Di Lorenzo \& Mantua 2016, Walsh et al. 2018). MHWs can have wide-reaching influence across food webs, from primary producers to top predators. Mass mortality events of seabirds and marine mammals have

(C) The authors and US Government (2019). Open Access under Creative Commons by Attribution Licence. Use, distribution and reproduction are unrestricted. Authors and original publication must be credited. 
been some of the most immediate and obvious ecosystem impacts tied to the Pacific heatwave and suggest bottom-up disruptions in energy transfer (Zador \& Yasumiishi 2017, Jones et al. 2018, Walsh et al. 2018). MHWs can also have socioeconomic repercussions including fishery closures and quota changes (Frölicher \& Laufkötter 2018, Oliver et al. 2018, Walsh et al. 2018).

Much of the energy transferred from lower to higher trophic levels in marine ecosystems passes through a small number of key forage fish species, making forage fish a focal point of bottom-up disruptions in energy transfer (Cury et al. 2000, Bakun 2006, Gaichas et al. 2015). Pacific sand lance Ammodytes personatus (named A. hexapterus prior to 2015, and hereafter called 'sand lance') is a key forage fish and high-quality prey species for piscivores in the Gulf of Alaska (Van Pelt et al. 1997, Robards et al. 1999a,c, Iverson et al. 2002, Abookire \& Piatt 2005, Piatt et al. 2018). Among the more than 100 known predators that rely on sand lance as an important food source (Robards et al. 1999c) are several species that dominate pelagic food webs, have special conservation status, or are targets of commercial, recreational, and subsistence fisheries. This includes seabirds such as common murre Uria aalge, tufted puffin Fratercula cirrhata, and black-legged kittiwake Rissa tridactyla; marine mammals such as humpback whale Megaptera novaeangliae and Steller sea lion Eumetopias jubatus; and large predatory fish such as Chinook salmon Oncorhynchus tshawytscha, coho salmon O. kisutch, Pacific cod Gadus macrocephalus, Pacific halibut Hippoglossus stenolepis, and various rockfish species (Sebastes spp.) (Brodeur 1990, Robards et al. 1999c, Yang et al. 1999, 2006, Litzow et al. 2002, Weitkamp \& Sturdevant 2008, Moss et al. 2016, Piatt et al. 2018).

While other forage fish species are usually consumed by a wide variety of predators, sand lance are a preferred indicator species due to their strong residency and generalist foraging strategy. These fish undergo minimal migrations and therefore may be considered residents that reflect the environmental conditions of their capture locations (Robards et al. 2002, Haynes \& Robinson 2011, Love 2011) and are more reliable for sampling. Sand lance residency is likely tied to their habitat requirements that include shallow, sandy substrates that are suitable for burrowing (Robards et al. 1999c). Sand lance are not selective foragers (Purcell \& Sturdevant 2001) and can provide an index for energy transferred through forage fish more generally. The dietary overlap between sand lance and other forage fish is high (Stur- devant et al. 1996), and they often feed together with other species including juvenile Pacific herring $\mathrm{Clu}$ pea pallasii (Ciannelli 1997).

Evidence suggests that the abundance and growth rates of sand lance are correlated with environmental conditions such as marine productivity and water temperatures (Litzow et al. 2000, 2002, Robards et al. 2002, Abookire \& Piatt 2005, Hatch 2013, Sydeman et al. 2017). In the Gulf of Alaska, sand lance have often thrived during warm years including the 1997-1998 El Niño (Litzow et al. 2000, 2002, Robards et al. 2002, Abookire \& Piatt 2005) and have become the primary forage fish prey for seabird predators during warm years (Hatch 2013, Sydeman et al. 2017). An opposite pattern with a negative relationship between sand lance recruitment (i.e. abundance of age- 0 sized fish) and temperature is well documented in the more temperate ecosystem of British Columbia (Canada) and is coupled with observations that predators rely on sand lance in primarily cool years (Bertram et al. 2001, Hedd et al. 2006). This difference in biophysical relationships between Alaska and British Columbia is consistent with differences in the bottom-up limits on primary production, with warm years benefitting the Gulf of Alaska through increases in water column stability, but cool years increasing primary production in British Columbia through increased mixing and relaxed nutrient limitation (Gargett 1997, Mueter et al. 2002, Black et al. 2008, von Biela et al. 2015).

We focused on indices of size and caloric nutritional value to assess the transfer of energy from lower trophic level consumers to predators. These indices are sensitive to temperature because of the direct influence on metabolic costs (Björnsson \& Steinarsson 2002, Peck et al. 2003, Laurel et al. 2016) and indirect influence of temperature on the quality of their zooplankton prey resources (Bertram et al. 2001, Brosset et al. 2015, Boldt et al. 2018). For example, zooplankton communities in the subarctic North Pacific tend to be dominated by lipid-rich larger species during cool periods and smaller species with lower lipid content and energy during warm periods (Mackas et al. 2007, Keister et al. 2011, Batten et al. 2018). Sand lance appear to benefit when lipid-rich zooplankton predominate in at least parts of their range (Bertram et al. 2001).

We examined sand lance nutritional value over a period of 5 yr (2012-2016) in which water temperatures warmed steadily from being relatively cool to extremely warm during the peak of the MHW. Sand lance were collected as part of the long-term ecosystem monitoring program of the 'Exxon Valdez' Oil 
Spill Trustee Council in Prince William Sound (PWS), Alaska (Aderhold et al. 2018, Arimitsu et al. 2018). We examined interannual differences in individual length-at-age, energy density, and whole-fish energy content in the 2 primary age classes of sand lance (age-0 and age-1) to assess differences in energy transfer to predators during the Pacific MHW. This suite of indices recognizes that individuals allocate energy to both somatic growth (i.e. length) and storage (i.e. energy density) (Biro et al. 2005) and that the total caloric value of a prey item (i.e. whole-fish energy) is an important index of nutritional value for sand lance predators, particularly those who capture fish one at a time, as many seabirds do (Wanless et al. 2018).

\section{MATERIALS AND METHODS}

\subsection{Study area}

PWS is a complex fjord-estuary located in southcentral Alaska (Fig. 1). Sea surface temperatures were extracted from daily satellite temperature data (https:// podaac.jpl.nasa.gov/dataset/MUR-JPL-L4-GLOB-v4.1) for an area near Naked Island in PWS to demonstrate that local temperature followed the broader pattern in the Gulf of Alaska and Pacific Ocean during this period (2012-2016). The area used was defined as

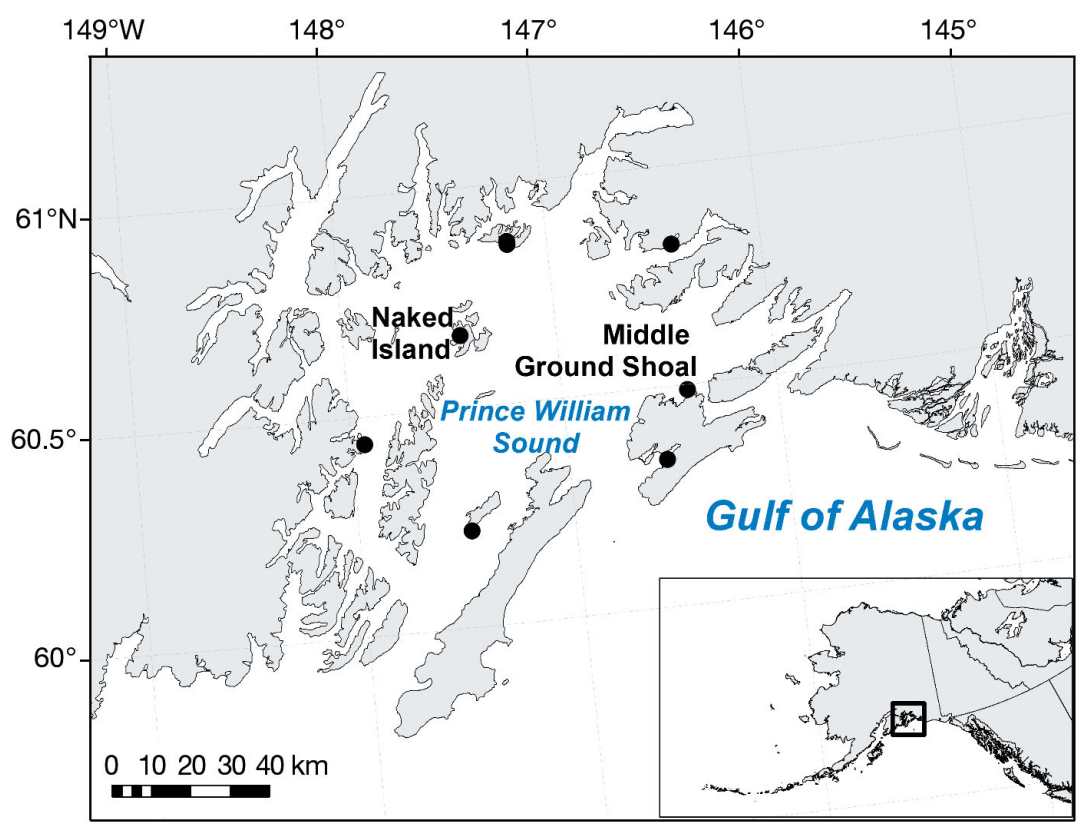

Fig. 1. Prince William Sound, Alaska, USA, showing sample collection locations (black circles). Approximately $70 \%$ of sand lance were collected from Naked Island and $24 \%$ from Middle Ground Shoal, with $<1 \%$ of samples from each additional collection location
Groundfish/Shellfish Statistical Area 476034 by the Alaska Department of Fish and Game. Data were averaged over monthly periods back to 2003, when the satellite dataset began, and we present data as anomalies in reference to the average temperature calculated over the data record, 2003-2016.

\subsection{Fish sample collection and analyses}

All Pacific sand lance were captured in July near the annual peak of body condition and lipid accumulation for sand lance in southcentral Alaska (Robards et al. 1999a). The timing of peak body condition is determined by a life history that includes fall spawning and winter hatching (Dick \& Warner 1982, Robards et al. 1999b), and coincides with the peak abundance of their primary prey, zooplankton (McKinstry \& Campbell 2018). Our assumption of minimal (<1 mo) interannual variation in the peak timing of sand lance body condition is supported by the consistent seasonality in the timing of peak chlorophyll a concentrations and zooplankton abundances (McKinstry \& Campbell 2018). Differences between sexes should be minimal during July (Robards et al. 1999a).

We collected sand lance for age composition and nutritional value using purse seine, beach seine, herring jig, cast net, dip net, and gill net. The purse seine was deployed from a skiff, and was $46.9 \mathrm{~m}$ long and $6.1 \mathrm{~m}$ deep, with mesh sizes of 32 and $3.2 \mathrm{~mm}$. The beach seine was set parallel to shore from a skiff and retrieved from the beach and was $37 \mathrm{~m}$ long with diminishing mesh size from $28 \mathrm{~mm}$ at the wings to $5 \mathrm{~mm}$ at the center. Herring jigs (hook size 4, 6, 8, and 10), cast nets (mesh size 6.4 and $19.1 \mathrm{~mm})$, long-handled dip nets (mesh size $5 \mathrm{~mm}$ ), and gill nets (18.2 $\mathrm{m} \times 4.9 \mathrm{~m}$ with variable mesh panels of $6.4,7.9$, and $9.5 \mathrm{~mm}$ square mesh) were used infrequently to sample small, shallow schools.

Fish total length was measured to the nearest $\mathrm{mm}$ from either freshly captured individuals at sea $\left(\mathrm{TL}_{\text {field }}\right)$ or thawed individuals in the laboratory $\left(\mathrm{TL}_{\mathrm{Lab}}\right)$. Length was measured for thawed fish in the laboratory for all years except 2015, when lengths were only measured in the field. In 2016, lengths were measured in both field and laboratory for each fish and 
the data were used to develop a linear regression equation to convert measurements between freshly captured and thawed sand lance $\left(\mathrm{TL}_{\text {field }}=1.03\right.$ $\left.\times \mathrm{TL}_{\text {Lab }}+1.58 ; \mathrm{r}^{2}=0.97, \mathrm{p}<0.0001\right)$.

Age was assigned by counting translucent annular rings on sagittal otoliths of sand lance by 2 independent, blind readers. In the event of disagreement in age assignment, readers re-examined an otolith jointly and assigned a consensus age for analysis. Otoliths were extracted, dried, and examined under reflected light using a Leica M60 dissection microscope. Under reflected light, translucent zones appear dark and opaque zones appear white (Fig. 2). Translucent bands forming on the otolith edge were considered incomplete, assuming a January 1 birth date for sand lance (Robards et al. 2002). We

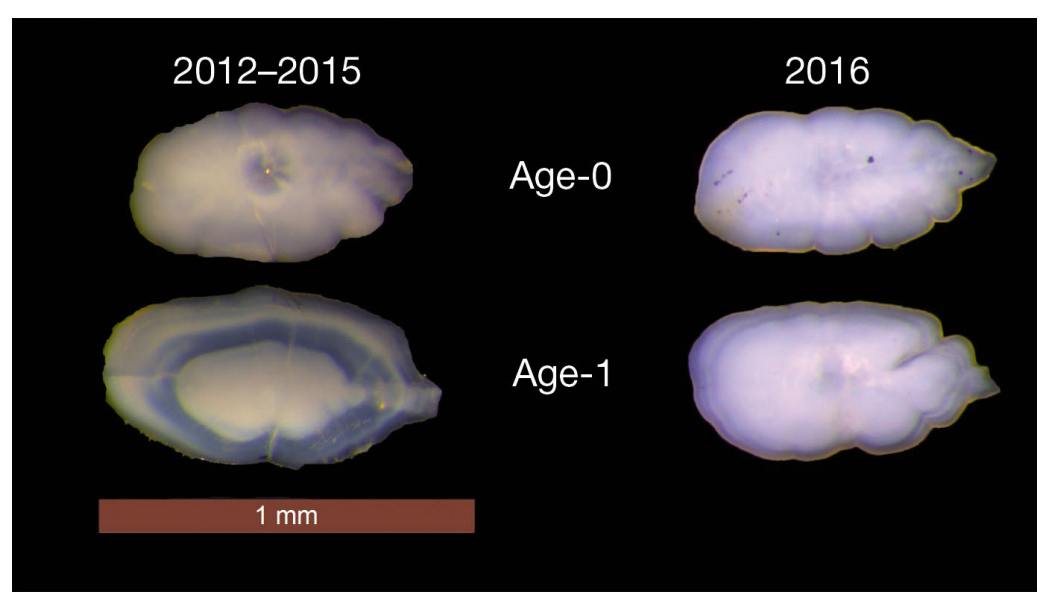

Fig. 2. Whole sagittal otoliths representative of age-0 (top row) and age-1 (bottom row) sand lance and the distinct difference in banding patterns between individuals captured in the years 2012-2015 (left column) and those captured in 2016 (right column). Images captured under reflected light through a dissection microscope. The white or opaque regions are composed of dense material with higher proportions of organic material during the season associated with rapid growth, while the dark or translucent areas are hyaline material deposited during the seasons of slower growth assumed consistent spawn and hatch timing among cohorts such that little variation $(\sim 1 \mathrm{mo})$ in mean age exists within each age class across years. Digital images of each otolith were captured using a Leica DFC425 digital camera.

To quantify the difference in otolith appearance among capture years, the 'plus' growth was measured for the same subset of age-1 sand lance randomly selected for energy density analyses $(n=50$, see below). The plus growth represents the growth that occurred within the spring-summer of collection and was measured from the outside edge of the translucent zone to the outside edge of the otolith along the longest axis from the nucleus to the edge. Otolith growth is strongly correlated to somatic size within fish species (Campana \& Thorrold 2001).

Energy density and whole-body energy were estimated using bomb calorimetry on a subset of samples following otolith removal and age assignment. Ten individuals were randomly selected within each primary age class (age-0, age-1) and collection year for energy density analysis $(\mathrm{n}=100)$. Whole fish were freeze-dried until weight stabilized and no moisture was apparent (approximately $48 \mathrm{~h}$ ). Dry mass was recorded to the nearest $0.0001 \mathrm{~g}$. Dried fish were homogenized using a mortar and pestle, and a pellet was pressed from a subsample and weighed immediately. A semimicro Parr 6725 calorimeter was used to measure energy density. Benzoic acid standards and duplicate tissue samples were used to evaluate precision.
Energy density is reported per unit dry mass $\left(\mathrm{kJ} \mathrm{g}^{-1}\right.$ dry mass), as wet mass measurements likely introduce a desiccation bias that can mask the true biological relationships (Montevecchi \& Piatt 1987, Hislop et al. 1991, Van Pelt et al. 1997, Ball et al. 2007). Whole-body energy ( $\mathrm{kJ}$ fish ${ }^{-1}$ ) was estimated by multiplying energy density ( $\mathrm{kJ} \mathrm{g}^{-1}$ dry mass) by dry mass (g). Energy density and whole-body energy were compared among years using 1-way analysis of variance (ANOVA) with Tukey's HSD post hoc test within each age class $(\alpha<0.05)$. The relationships between length and energy density or whole-body energy were examined using simple linear regression with $\log -\log$ transformations (Andrews et al. 2009).

\section{RESULTS}

\subsection{Temperature anomalies}

Sea surface temperature anomalies in the Naked Island area of PWS indicate cool monthly temperatures in the 12 mo preceding sand lance collections each July for the years 2012 and 2013, near average or slightly warm temperatures prior to collection in 2014, and primarily above average temperature prior to 2015 and 2016 collections (Fig. 3). Temperature anomalies prior to collections in the 2 warm years peaked predominantly in the winter for 2015 and in 


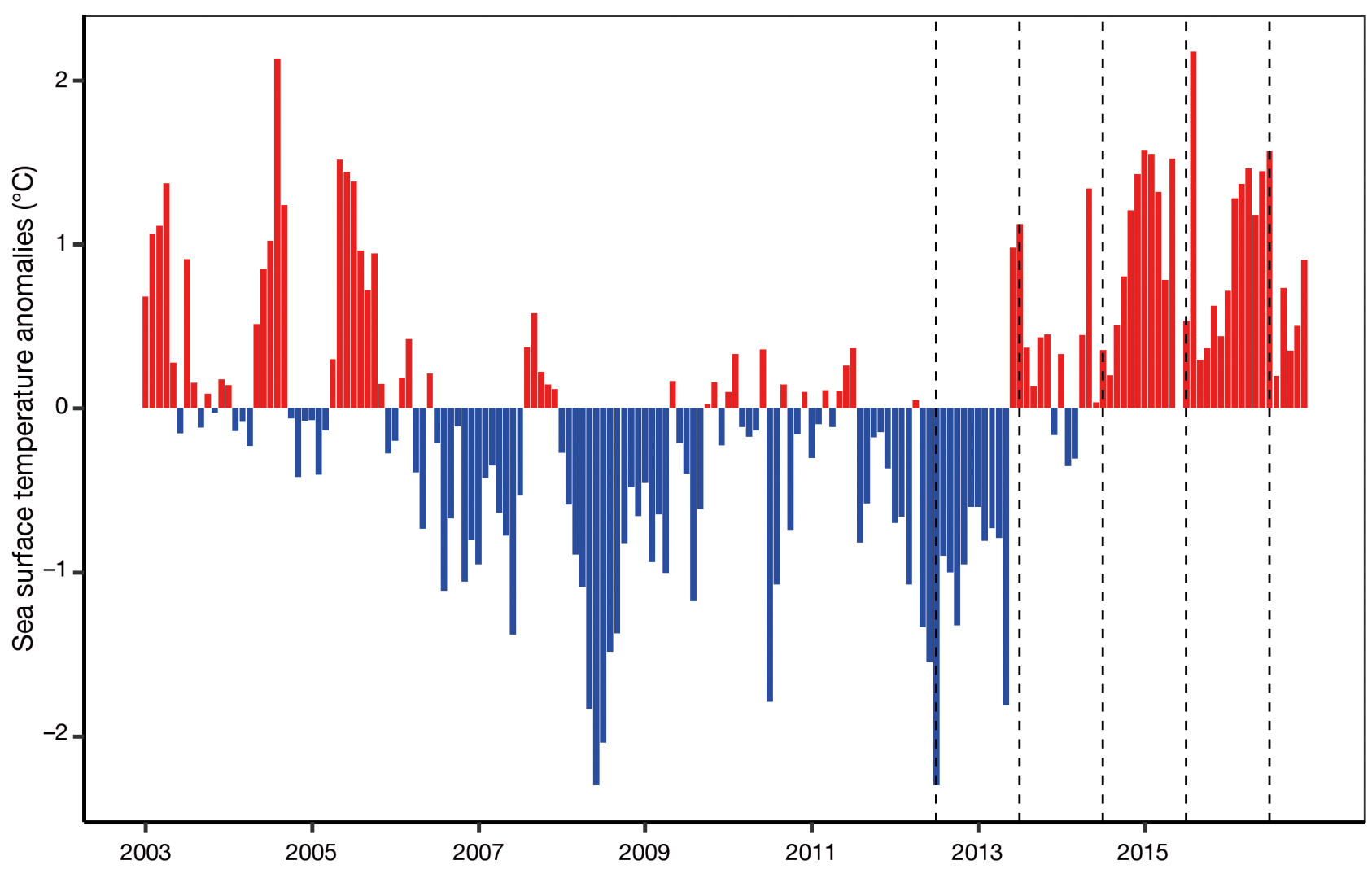

Fig. 3. Monthly sea surface temperature anomalies for the area near Naked Island in Prince William Sound, Alaska, as defined by the Alaska Department of Fish and Game Groundfish/Shellfish Statistical Area 476034 by calendar year. Anomalies are calculated as the difference (red: positive; blue: negative) from the monthly mean for the years 2003-2016 (reported in Table A1). Dashed lines indicate timing (i.e. July) of Pacific sand lance collections in 2012-2016

the spring-summer for 2016. The absolute maximum monthly temperatures in the summers of $2015(\mathrm{Au}-$ gust: $15.8^{\circ} \mathrm{C}$ ) and 2016 (July: $15.3^{\circ} \mathrm{C}$ ) were similar to those in 2004 (August: $15.7^{\circ} \mathrm{C}$ ) and 2005 (July: $15.2^{\circ} \mathrm{C}$ ). However, the persistence of the anomalies from late 2014 through 2015 and 2016 across nearly all months differed from the prior warm years of 2004 and 2005. Absolute mean monthly temperatures are reported in Table A1 in the Appendix.

\subsection{Sand lance collections}

During 5 yr of sampling, 539 sand lance were examined for age and length, with otoliths identifying individuals as primarily age-0 (45\%) and age-1 $(48 \%)$. Age-2 sand lance were captured each year, but low sample size precluded a robust examination of interannual variability. Nearly all (>95\%) otoliths were examined by both age readers, and age assignment among those age classes included in this study was $98 \%$. These sand lance were often captured by purse seine $(40 \%)$ and dip net $(26 \%)$, with smaller con- tributions from cast net $(14 \%)$, beach seine $(12 \%)$, gill net $(7 \%)$, and jig $(2 \%)$. All gear types captured both age- 0 and age- 1 individuals consistently spanning the size range from approximately 60 to $130 \mathrm{~mm}$ TL. Sand lance were most often captured near the coast of Naked Island (70\%) or Middle Ground Shoal (24\%) (Fig. 1). In most years, age-0 and age-1 sand lance were collected near Naked Island, but in 2015 only age-0 individuals were present at this location. In 2015, age-1 individuals were exclusively collected from Middle Ground Shoal. Other locations throughout PWS (Fig. 1) resulted in few collections (a total of $\leq 10$ across all years).

In 2016, unusual observations were made in the field and laboratory. In the field, only 1 size class of sand lance was observed, rather than the 2 distinct size classes that usually correspond to age- 0 and age-1+ individuals. A concerted effort to find larger fish was made throughout PWS without success. In the laboratory, otoliths revealed that this small size class was actually comprised of both age- 0 and age$1+$ sand lance. The otoliths of age-1 sand lance were markedly different from those examined in previous 
years, with very narrow translucent and opaque zones for the growth during age-1 (Fig. 2). This abnormal annulus could be distinguished from other non-annular translucent bands (e.g. false annuli) based on the clarity and continuity. The plus growth from age-1 fish captured in 2016 was less than half of that from previous years, which were all statistically similar $\left(\right.$ ANOVA, $F_{4,44}=15.6, \mathrm{p}<0.001$; Tukey HSD, $p<0.001)$. Despite differences in otolith macrostructure of age-1 individuals among years, a typical age-0 pattern otolith with near uniform opaque tissue (Macer 1966, Robards et al. 2002) was present in all years and continued to distinguish age-0 individuals from other age classes.

\subsection{Condition of age-0 sand lance}

Age-0 sand lance were longer in 2012 than any other sample year, with a mean difference of approximately $15 \mathrm{~mm}$ (ANOVA, $F_{4,240}=20.3, \mathrm{p}<0.001$; Tukey HSD, $\mathrm{p}<0.001$ for each pairwise comparison) (Fig. 4a). Age-0 sand lance collected in 2016 were also longer than those collected in 2015 by about $6 \mathrm{~mm}$ (Tukey HSD, $\mathrm{p}=0.006$ ). The energy density of age-0 sand lance was similar across years (ANOVA, $F_{4,50}=1.46, \mathrm{p}=0.232$ ) with a mean $\pm \mathrm{SD}$ of $18.9 \pm$ $2.12 \mathrm{~kJ} \mathrm{~g}^{-1}$ dry mass (Fig. 4b). Whole-body energy varied among years $\left(\right.$ ANOVA, $F_{4,50}=3.31, \mathrm{p}=$ $0.0186)$, with slightly higher energy in 2012 compared to 2014 (Tukey HSD pairwise $p=0.0272$ ) and $2015(\mathrm{p}=0.0232)$ (Table 1, Fig. 4c).

\subsection{Condition of age- 1 sand lance}

Age-1 sand lance were shorter in 2015 and 2016 compared to 2012-2014 (ANOVA, $F_{4,252}=203.2, \mathrm{p}<$ 0.001 ; Tukey HSD, $\mathrm{p}<0.001$ for each pairwise comparison) (Fig. 4a). The mean length of an age- 1 sand lance dropped from $127 \mathrm{~mm}$ in the first 3 years of study (2012-2014) to $112 \mathrm{~mm}$ in 2015 and $79 \mathrm{~mm}$ in 2016, representing a $38 \%$ decline in length compared to the 2012-2014 mean. Due to the decline in the length of age- 1 fish, the 2 age classes of sand lance became indistinguishable in length in 2016 (Fig. 4a).

The energy density of age-1 fish varied across years (ANOVA, $F_{4,50}=14.9, \mathrm{p}<0.001$ ), with higher energy density from 2013-2015 and lower energy density in 2012 (Tukey HSD, p < 0.02 for pairwise comparisons to 2013-2015) and 2016 (Tukey HSD, $\mathrm{p}<0.001$ for pairwise comparisons to 2013-2015)
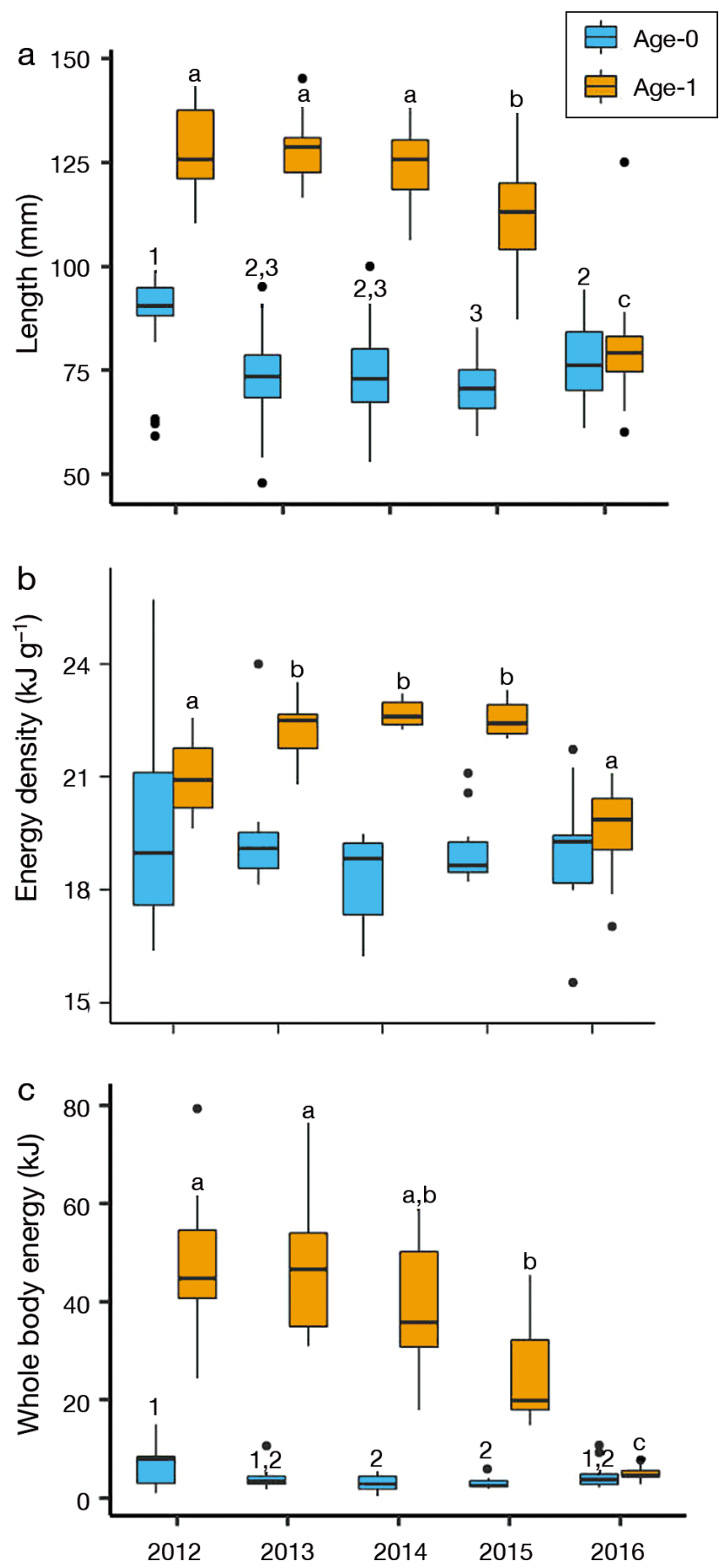

Fig. 4. (a) Length, (b) energy density, and (c) whole-body energy of age-0 (blue) and age-1 (orange) Pacific sand lance captured in Prince William Sound, Alaska, in 2012-2016. Energy density is reported in dry mass units. In each boxplot, the horizontal line is the median, the upper and lower ends of the box represent the first and third quartiles, the upper and lower whiskers extend to the highest and lowest values that are within $1.5 \times$ the inter-quartile range, and points denote outliers. Different numbers (age-0) or letters (age-1) among years denote significant pairwise differences in the mean value based on 1-way ANOVA with Tukey's HSD post hoc test $(\mathrm{p}<0.05)$ 
Table 1. Total length (mm), energy density ( $\mathrm{kJ} \mathrm{g}^{-1}$ dry mass), and wholebody energy (kJ) of age-0 and age-1 Pacific sand lance captured each July in Prince William Sound, Alaska, USA, with sample size for length $\left(\mathrm{N}_{\mathrm{L}}\right)$ and energy analyses $\left(\mathrm{N}_{\mathrm{E}}\right)$. Reported values are means $\pm \mathrm{SD}$ for each capture year and the overall mean for the age class

\begin{tabular}{|ccccccc|}
\hline $\begin{array}{l}\text { Sand } \\
\text { lance }\end{array}$ & Year & Length & $\mathrm{N}_{\mathrm{L}}$ & $\begin{array}{c}\text { Energy } \\
\text { density }\end{array}$ & $\begin{array}{c}\text { Whole-body } \\
\text { energy }\end{array}$ & $\mathrm{N}_{\mathrm{E}}$ \\
\hline Age-0 & 2012 & $88.4 \pm 10.8$ & 26 & $19.6 \pm 2.81$ & $7.06 \pm 4.62$ & 10 \\
& 2013 & $73.1 \pm 8.63$ & 55 & $19.4 \pm 1.69$ & $4.15 \pm 2.48$ & 10 \\
& 2014 & $73.7 \pm 9.34$ & 56 & $17.6 \pm 2.59$ & $3.11 \pm 1.67$ & 10 \\
& 2015 & $70.9 \pm 6.83$ & 60 & $19.1 \pm 0.99$ & $3.03 \pm 1.12$ & 10 \\
& 2016 & $76.6 \pm 8.68$ & 48 & $18.9 \pm 1.76$ & $4.82 \pm 2.89$ & 10 \\
& Overall & $75.0 \pm 9.94$ & 245 & $18.9 \pm 2.11$ & $4.43 \pm 3.09$ & 50 \\
Age-1 & 2012 & $128 \pm 9.57$ & 26 & $21.0 \pm 0.98$ & $48.1 \pm 16.4$ & 10 \\
& 2013 & $128 \pm 6.63$ & 33 & $22.8 \pm 1.78$ & $46.6 \pm 14.0$ & 10 \\
& 2014 & $124 \pm 8.14$ & 24 & $22.7 \pm 0.35$ & $39.7 \pm 13.6$ & 10 \\
& 2015 & $112 \pm 11.2$ & 119 & $22.5 \pm 0.48$ & $25.0 \pm 10.0$ & 10 \\
& 2016 & $78.8 \pm 8.93$ & 55 & $19.7 \pm 1.22$ & $5.04 \pm 1.45$ & 10 \\
& Overall & $110 \pm 20.0$ & 257 & $21.7 \pm 1.60$ & $32.6 \pm 20.1$ & 50 \\
\hline
\end{tabular}

fish energy) and the implication that energy transfer to higher trophic levels was disrupted through a species that has become more important to some predators in warm years. The longer, higher-quality sand lance appeared to be missing in 2016 based on the finding that age-1 fish became indistinguishable from age-0 fish and longer fish were not observed during field work despite efforts to sample them. Our findings provide a clear mechanism to explain how the Pacific MHW could result in predator reproductive failures and mortality.

The energy densities of sand lance observed in this study were similar to those reported previously in Alaska (Van Pelt et al. 1997, Robards et al. 1999a, 2002), but even a slight reduction in energy density, coupled with a significant reduction in

(Table 1, Fig. 4b). Whole-body energy also varied among years (ANOVA, $F_{4,50}=21.7, \mathrm{p}<0.001$ ) with declining energy from 2012 to 2016 (Fig. 4c). Wholebody energy was highest in 2012 and 2013, significantly lower in 2015, and lowest in 2016. Sand lance had $44 \%$ less total energy per fish in 2015 and $89 \%$ less total energy per fish in 2016 compared to the average whole-body energy of 2012-2014. In 2016, there was no difference in whole-body energy of age- 1 and age- 0 sand lance ( $t$-test, $\mathrm{p}=0.840$ ).

Length was positively related to both energy density and whole-body energy as a log-log relationship that spanned both age classes. The relationship between energy density ( $\mathrm{kJ} \mathrm{g}^{-1}$ dry mass) and length $(\mathrm{mm})$ is described by the equation $\log$ (energy density) $=7.45 \times \log ($ length $)-59.5\left(\mathrm{r}^{2}=0.490 ; \mathrm{p}<0.001\right)$. The relationship between whole-body energy $(\mathrm{kJ})$ and length $(\mathrm{mm})$ is $\log$ (whole-body energy) $=0.210 \times$ $\log ($ length $)+4.02\left(\mathrm{r}^{2}=0.956 ; \mathrm{p}<0.001\right)$.

\section{DISCUSSION}

We documented a significant decline in nutritional value of a key forage fish, Pacific sand lance, during a prolonged period of anomalously warm ocean conditions in the North Pacific Ocean. Local sea surface temperature anomalies generally followed patterns reported elsewhere (Di Lorenzo \& Mantua 2016, Campbell 2018, Walsh et al. 2018), indicating that local conditions reflected the Pacific MHW. These results are ecologically significant given the dramatic magnitude of decline (89\% decrease in age-1 whole- size (Table 1, Fig. 4), can result in dramatically lower overall whole-body energy and energy transfer. Thus, whole-body energy metrics are the most appropriate indicators to consider, as they reflect contributions from both declining size and energy storage.

The 2015 sand lance cohort appeared to experience little growth or lipid accumulation from July 2015 (at age-0) to July 2016 (at age-1). Detecting this pattern required otolith-based aging and would not have been possible if age was assumed from length, a common practice for forage fish (Hatch \& Sanger 1992, Hedd et al. 2006, Hatch 2013, Boldt et al. 2018). A similar lack of growth and abnormal otolith appearance has been described from a congeneric species in the North Sea (lesser sandeel Ammodytes marinus) and also resulted in similar sizes between 2 age classes that are typically distinct (Macer 1966).

It is unlikely that aging error explains patterns described in this study given that the results in 2016 followed a pattern that emerged in 2015, the consistency in age assignments between readers, and the presence of the standard age- 0 otolith pattern in all collection years (Fig. 2). In addition, age-0 and age-1 individuals collected in 2016 were often acquired together in a single gear deployment, suggesting shared environmental conditions. If the translucent zone was a false annulus resulting from a stressful event, all individuals captured together would be expected to show a similar macrostructure pattern. The otolith macrostructure patterns observed in 2016 could have made it more difficult to distinguish between age- 1 and age- 2 individuals. Given that age- 2 individuals are similar or larger than age-1 sand 
lance, such a bias would lead us to an overestimation of growth and is opposite of the pattern observed. Interannual variation in mean hatch date also fails to explain the changes in length-at-age, as warmer years should be associated with faster development, earlier hatch dates, and older individuals (Frederiksen et al. 2011) that reach longer lengths if growth rates are also consistent.

The lower energy densities and lack of lipid accumulation among age-1 sand lance in 2016 follows an energy allocation strategy that prioritizes somatic growth over lipid accumulation until sand lance reach $\sim 80 \mathrm{~mm}$ (Robards et al. 1999a), and strong sizeselective mortality among shorter individuals (Biro et al. 2005). The mean size of age-1 individuals captured in 2016 was $79 \mathrm{~mm}$, and just at the size when increases in lipid and energy are expected. In comparison, little change in nutritional value was observed for age-0 sand lance among years, and the variability was not clearly related to the MHW. Juvenile sand lance near or below the $80 \mathrm{~mm}$ size threshold channel energy to protein and growth rather than stored lipids, which results in consistent low energy densities. Thus, juveniles (i.e. age-0), have both less lipid and less protein (as indicated by shorter length) to buffer against starvation compared to adults (i.e. age-1 and older in Robards et al. 1999a). The result appears to show that there is less room for variation in nutritional value of juveniles and likely a higher risk of mortality when conditions are poor as compared to adults. This may explain why a decline in the nutritional value of age-0 sand lance was not apparent in our samples.

The dramatic decline in sand lance whole-body energy that we observed during the MHW may have resulted from poor quantity or quality of their prey resources. Sand lance abundance and condition have previously been linked to lower trophic production (Litzow et al. 2002, Robards et al. 2002), and concurrent observations suggest that this pattern continues, although without the positive relationship to temperature. The extremely warm and persistent conditions resulted in stronger stratification and diminished vertical mixing (Walsh et al. 2018), which could have impeded the replenishment of key nutrients in surface waters over the winter that usually sets the stage for a spring bloom (Weingartner et al. 2002, Childers et al. 2005). The apparent result was the lowest chlorophyll estimate for April through August 2016 from MODIS satellites in the $14 \mathrm{yr}$ record (2003-2016) (Hopcroft et al. 2018). A similar response to the Pacific MHW with low nutrients and chlorophyll was recently documented in British Columbia (Peña et al. 2018).
The variation in sand lance condition described here mirrors spring chlorophyll anomalies in the northern Gulf of Alaska, with high primary production in the years 2012-2014 and low production in 2015 and 2016 (Hopcroft et al. 2018). Reductions in diatoms and zooplankton as conditions warmed from 2014 to 2015 were also noted despite a previous positive relationship with temperature from 2000 to 2013 (Batten et al. 2018, McKinstry \& Campbell 2018). Furthermore, the diatom community was dominated by species with long, narrow cells during the MHW, which tends to occur with nutrient limitation (Batten et al. 2018). Findings such as these raise the possibility that water column stability in the Gulf of Alaska increased beyond an optimum during the MHW and passed a fundamental tipping point from primarily light- to primarily nutrient-limited under the optimal stability framework (Gargett 1997) with biophysical relationships that are more similar to those observed in British Columbia due to nutrient limitation (Bertram et al. 2001, Hedd et al. 2006). In other words, the simple positive linear relationship between temperature and production that has often prevailed in the Gulf of Alaska may no longer be a good simplifying assumption as conditions warm and the domeshaped relationship describing the balance between light and nutrient limitation becomes more apparent. Other authors have similarly suggested that a domeshaped relationship exists for sand lance response to temperature in British Columbia (Bertram et al. 2001, Hedd et al. 2006).

A rapid decline in growth and condition can also occur when temperature exceeds the species-specific physiological optimum (Björnsson \& Steinarsson 2002, Peck et al. 2003, Laurel et al. 2016). While the increased temperatures probably did increase metabolic costs for sand lance, sea surface temperatures during the warmest months (e.g. summer) were not beyond the realm of those previously measured in warm years (Fig. 3), and it seems unlikely that the rapid decline in condition could be attributed to temperature alone because PWS is near the northern distribution limit for the species (Orr et al. 2015), and eurythermal species (Robards et al. 1999c) tend to have more gradual responses to exceeding temperature optimums (Laurel et al. 2016). Furthermore, sand lance may behaviorally modify metabolic costs by adjusting daily and seasonal periods of dormancy when buried (Robards et al. 1999b, Tomiyama \& Yanagibashi 2004). Periods of dormancy are characterized by reduced metabolism and resistance to starvation (Quinn \& Schneider 1991, Ciannelli 1997, Tomiyama \& Yanagibashi 2004, Behrens \& Steffen- 
sen 2007). Thus, sand lance response to the MHW could reflect poor feeding conditions alone, or, more likely, a combination of poor feeding conditions and increased metabolic costs.

As a key prey species for most piscivorous predators in the North Pacific, the nutritional value of sand lance was likely a factor in associated ecosystem responses to the MHW (Walsh et al. 2018). In particular, lower sand lance nutritional value in 2015 and 2016 could help explain declines in common murre breeding success associated with the MHW (Zador \& Yasumiishi 2017, Dragoo et al. 2018), as sand lance are a primary prey of murres during the summer breeding season (Piatt \& Anderson 1996). Availability and condition of various sandeels (Ammodytes spp.) has been tied to reproductive success and survival of predators elsewhere (Bertram \& Kaiser 1993, Wanless et al. 2005, Furness 2007). Indeed, one of the worst years for breeding success of murres in the North Sea coincided with a reduction in both size and energy density of sandeels in 2004 (Wanless et al. 2005). More broadly, community-level changes in seabird diets in the North Sea during the past few decades reflect a reduction in sandeel abundance and size (Wanless et al. 2018).

It is not yet clear how many predators in the Gulf of Alaska were affected by the MHW because the effects on recruitment may take years to be realized by wildlife monitoring, fishery catches, or salmon escapement. At present, reports suggest that the MHW was associated with declines in abundance of capelin Mallotus villosus, sand lance, and Pacific cod, lower bottom trawl biomass of aggregated fish and invertebrates, lower energy density in herring, lower growth rates of rhinoceros auklet Cerorhinca monocerata chicks and production, and reduced calving rates and poor body condition for humpback whales (Zador \& Yasumiishi 2017, Gorman et al. 2018). These observations resulted in an $80 \%$ drop in the Pacific cod acceptable biological catch for 2018 and a plan to maintain low quotas in 2019 and 2020 (Barbeaux et al. 2018). Given the increasing frequency and duration of MHWs (Oliver et al. 2018) and the likelihood that new temperature extremes are surpassing important biophysical and metabolic tipping points, studies like this are necessary to evaluate assumptions that inform management actions and are embedded in predictive ecosystem models.

Acknowledgements. Funding was provided by the 'Exxon Valdez' Oil Spill Trustee Council and US Geological Survey (USGS) Alaska Science Center. C.M.C. was supported through an Alaska Sea Grant Fellowship hosted by the
USGS. We thank Greg Snedgen, the captain of the USGS RV 'Alaskan Gyre,' as well as Jonathan Felis, Jamie King, Mike Larson, and Erica Madison for their help in the field and Jordan Watson for extracting and making available the sea surface temperature data. The findings and conclusions presented here do not necessarily reflect the views or positions of the 'Exxon Valdez' Oil Spill Trustee Council. Any use of trade names or products is for descriptive purposes only and does not imply endorsement of the US Government.

\section{LITERATURE CITED}

Abookire AA, Piatt JF (2005) Oceanographic conditions structure forage fishes into lipid-rich and lipid-poor communities in lower Cook Inlet, Alaska, USA. Mar Ecol Prog Ser 287:229-240

Aderhold DG, Lindeberg MR, Holderied K, Pegau WS (2018) Spatial and temporal ecological variability in the northern Gulf of Alaska: What have we learned since the Exxon Valdez oil spill? Deep-Sea Res II 147:3-8

Andrews AG, Farley EV, Moss JH, Murphy JM, Husoe EF (2009) Energy density and length of juvenile pink salmon Oncorhynchus gorbuscha in the eastern Bering Sea from 2004 to 2007: a period of relatively warm and cool sea surface temperatures. North Pac Anadromous Fish Comm Bull 5:183-189

Arimitsu ML, Piatt JF, Heflin B, von Biela VR, Schoen SK (2018) Monitoring long-term changes in forage fish distribution, abundance and body condition. Exxon Valdes Oil Spill Restoration Project Final Report (Restoration Project 16120114-O). US Geological Survey, Alaska Science Center, Anchorage, AK

*Bakun A (2006) Wasp-waist populations and marine ecosystem dynamics: navigating the 'predator pit' topographies. Prog Oceanogr 68:271-288

Ball JR, Esler D, Schmutz JA (2007) Proximate composition, energetic value, and relative abundance of prey fish from the inshore eastern Bering Sea: implications for piscivorous predators. Polar Biol 30:699-708

Barbeaux S, Aydin K, Fissel B, Holsman K and others (2018) Assessment of the Pacific cod stock in the Gulf of Alaska. In: Stock assessment and fishery evaluation report for the groundfish resources of the Gulf of Alaska. North Pacific Fishery Management Council, Anchorage, AK

Batten SD, Raitsos DE, Danielson S, Hopcroft R, Coyle K, McQuatters-Gollop A (2018) Interannual variability in lower trophic levels on the Alaskan Shelf. Deep-Sea Res II 147:58-68

Behrens JW, Steffensen JF (2007) The effect of hypoxia on behavioural and physiological aspects of lesser sandeel, Ammodytes tobianus (Linnaeus, 1785). Mar Biol 150: 1365-1377

* Bertram DF, Kaiser GW (1993) Rhinoceros auklet (Cerorhinca monocerata) nestling diet may gauge Pacific sand lance (Ammodytes hexapterus) recruitment. Can J Fish Aquat Sci 50:1908-1915

* Bertram DF, Mackas DL, Mckinnell SM (2001) The seasonal cycle revisited: interannual variation and ecosystem consequences. Prog Oceanogr 49:283-307

Biro PA, Post JR, Abrahams MV (2005) Ontogeny of energy allocation reveals selective pressure promoting risktaking behaviour in young fish cohorts. Proc R Soc B 272: 1443-1448 
Björnsson B, Steinarsson A (2002) The food-unlimited growth rate of Atlantic cod (Gadus morhua). Can J Fish Aquat Sci 59:494-502

Black BA, Boehlert GW, Yoklavich MM (2008) Establishing climate-growth relationships for yelloweye rockfish (Sebastes ruberrimus) in the northeast Pacific using a dendrochronological approach. Fish Oceanogr 17:368-379

Boldt JL, Thompson M, Rooper CN, Hay DE and others (2018) Bottom-up and top-down control of small pelagic forage fish: factors affecting age-0 herring in the Strait of Georgia, British Columbia. Mar Ecol Prog Ser, https:// doi.org/10.3354/meps12485

Brodeur RD (1990) A synthesis of the food habits and feeding ecology of salmonids in marine waters of the North Pacific. INPFC Doc FRI-UW-9016. Fisheries Research Institute, University of Washington, Seattle, WA

Brosset P, Ménard F, Fromentin JM, Bonhommeau S and others (2015) Influence of environmental variability and age on the body condition of small pelagic fish in the Gulf of Lions. Mar Ecol Prog Ser 529:219-231

Campana SE, Thorrold SR (2001) Otoliths, increments, and elements: keys to a comprehensive understanding of fish populations? Can J Fish Aquat Sci 58:30-38

Campbell RW (2018) Hydrographic trends in Prince William Sound, Alaska, 1960-2016. Deep-Sea Res II 147:43-57

Childers AR, Whitledge TE, Stockwell DA (2005) Seasonal and interannual variability in the distribution of nutrients and chlorophyll a across the Gulf of Alaska shelf: 1998-2000. Deep-Sea Res II 52:193-216

Ciannelli L (1997) Winter dormancy in the Pacific sand lance (Ammodytes hexapterus) in relation to gut evacuation time. In: Forage fishes in marine ecosystems. Proceedings of the International Symposium on the Role of Forage Fishes in Marine Ecosystems. Alaska Sea Grant College Program, Report No. 97-01. University of Alaska Fairbanks, Fairbanks, AK, p 95-104

Cury P, Bakun A, Crawford RJM, Jarre A, Quiñones RA, Shannon LJ, Verheye HM (2000) Small pelagics in upwelling systems: patterns of interaction and structural changes in 'wasp-waist' ecosystems. ICES J Mar Sci 57: 603-618

Di Lorenzo E, Mantua N (2016) Multi-year persistence of the 2014/15 North Pacific marine heatwave. Nat Clim Chang 6:1042-1047

Dick MH, Warner IM (1982) Pacific sand lance, Ammodytes hexapterus Pallas, in the Kodiak Island group, Alaska. Syesis 15:43-50

Dragoo DE, Renner HM, Kaler RSA (2018) Breeding status and population trends of seabirds in Alaska, 2017. US Fish Wildl Serv Rep ANBWR 2018/02. USFWS, Homer, AK

Frederiksen M, Elston DA, Edwards M, Mann AD, Wanless S (2011) Mechanisms of long-term decline in size of lesser sandeels in the North Sea explored using a growth and phenology model. Mar Ecol Prog Ser 432:137-147

Frölicher TL, Laufkötter C (2018) Emerging risks from marine heat waves. Nat Commun 9:650

Furness RW (2007) Responses of seabirds to depletion of food fish stocks. J Ornithol 148(Suppl 2):247-252

Gaichas S, Aydin K, Francis RC (2015) Wasp waist or beer belly? Modeling food web structure and energetic control in Alaskan marine ecosystems, with implications for fishing and environmental forcing. Prog Oceanogr 138: $1-17$

Gargett AE (1997) The optimal stability 'window': a mechanism underlying decadal fluctuations in North Pacific salmon stocks? Fish Oceanogr 6:109-117

Gorman KB, Kline TC Jr, Roberts ME, Sewall FF, Heintz RA, Pegau WS (2018) Spatial and temporal variation in winter condition of juvenile Pacific herring (Clupea pallasii) in Prince William Sound, Alaska: oceanographic exchange with the Gulf of Alaska. Deep-Sea Res II 147: 116-126

Hatch SA (2013) Kittiwake diets and chick production signal a 2008 regime shift in the Northeast Pacific. Mar Ecol Prog Ser 477:271-284

Hatch SA, Sanger GA (1992) Puffins as samplers of juvenile pollock and other forage fish in the Gulf of Alaska. Mar Ecol Prog Ser 80:1-14

*Haynes TB, Robinson CLK (2011) Re-use of shallow sediment patches by Pacific sand lance (Ammodytes hexapterus) in Barkley Sound, British Columbia, Canada. Environ Biol Fishes 92:1-12

KHedd A, Bertram DF, Ryder JL, Jones IL (2006) Effects of interdecadal climate variability on marine trophic interactions: rhinoceros auklets and their fish prey. Mar Ecol Prog Ser 309:263-278

* Hislop JRG, Harris MP, Smith JGM (1991) Variation in the calorific value and total energy content of the lesser sandeel (Ammodytes marinus) and other fish preyed on by seabirds. J Zool (Lond) 224:501-517

Hopcroft RR, Danielson SL, Strom S, Kuletz K (2018) The Seward Line: marine ecosystem monitoring in the Northern Gulf of Alaska. Exxon Valdez Oil Spill Long-Term Monitoring Program (Gulf Watch Alaska) Final Report. (Exxon Valdez Oil Spill Trustee Council Project 16120114J). Exxon Valdez Oil Spill Trustee Council, Anchorage, AK. http://gulfwatchalaska.org/wp-content/uploads/2018/ 08/16120114-J-Hopcroft-et-al.-2018-Final-Report.pdf

Hu ZZ, Kumar A, Jha B, Zhu J, Huang B (2017) Persistence and predictions of the remarkable warm anomaly in the northeastern Pacific Ocean during 2014-16. J Clim 30: 689-702

* Iverson SJ, Frost KJ, Lang SLC (2002) Fat content and fatty acid composition of forage fish and invertebrates in Prince William Sound, Alaska: factors contributing to among and within species variability. Mar Ecol Prog Ser 241:161-181

Jones T, Parrish JK, Peterson WT, Bjorkstedt EP and others (2018) Massive mortality of a planktivorous seabird in response to a marine heatwave. Geophys Res Lett 45: 3193-3202

Keister JE, Di Lorenzo E, Morgan CA, Combes V, Peterson WT (2011) Zooplankton species composition is linked to ocean transport in the Northern California Current. Glob Change Biol 17:2498-2511

K Laurel BJ, Spencer M, Iseri P, Copeman LA (2016) Temperature-dependent growth and behavior of juvenile Arctic cod (Boreogadus saida) and co-occurring North Pacific gadids. Polar Biol 39:1127-1135

* Litzow MA, Piatt JF, Abookire AA, Prichard AK, Robards MD (2000) Monitoring temporal and spatial variability in sandeel (Ammodytes hexapterus) abundance with pigeon guillemot (Cepphus columba) diets. ICES J Mar Sci 57:976-986

* Litzow MA, Piatt JF, Prichard AK, Roby DD (2002) Response of pigeon guillemots to variable abundance of high-lipid and low-lipid prey. Oecologia 132:286-295

Love MS (2011) Certainly more than you want to know about the fishes of the Pacific Coast. Really Big Press, Santa Barbara, CA 
Macer C (1966) Sand eels (Ammodytidae) in the south-western North Sea; their biology and fishery. Ministry of Agriculture, Fisheries and Food, Fishery Investigation London 24:1-55

Mackas DL, Batten S, Trudel M (2007) Effects on zooplankton of a warmer ocean: recent evidence from the northeast Pacific. Prog Oceanogr 75:223-252

McKinstry CAE, Campbell RW (2018) Seasonal variation of zooplankton abundance and community structure in Prince William Sound, Alaska, 2009-2016. Deep-Sea Res II 147:69-78

Montevecchi WA, Piatt JF (1987) Dehydration of seabird prey during transport to the colony: effects on wet weight energy densities. Can J Zool 65:2822-2824

Moss JH, Murphy JM, Fergusson EA, Heintz RA (2016) Allometric relationships between body size and energy density of juvenile chinook (Oncorhynchus tshawytscha) and chum $(O$. keta) salmon across a latitudinal gradient. North Pac Anadromous Fish Comm Bull 6:161-168

* Mueter FJ, Peterman RM, Pyper BJ (2002) Opposite effects of ocean temperature on survival rates of 120 stocks of Pacific salmon (Oncorhynchus spp.) in northern and southern areas. Can J Fish Aquat Sci 59:456-463

Oliver ECJ, Donat MG, Burrows MT, Moore PJ and others (2018) Longer and more frequent marine heatwaves over the past century. Nat Commun 9:1324

* Orr JC, Wildes S, Kai Y, Raring N, Nakabo T, Katugin O, Guyon J (2015) Systematics of North Pacific sand lances of the genus Ammodytes based on molecular and morphological evidence, with the description of a new species from Japan. Fish Bull 113:129-156

Peck MA, Buckley LJ, Caldarone EM, Bengtson DA (2003) Effects of food consumption and temperature on growth rate and biochemical-based indicators of growth in early juvenile Atlantic cod Gadus morhua and haddock Meanogrammus aeglefinus. Mar Ecol Prog Ser 251:233-243

Peña MA, Nemcek N, Robert M (2018) Phytoplankton responses to the 2014-2016 warming anomaly in the northeast subarctic Pacific Ocean. Limnol Oceanogr https:// doi.org/10.1002/lno.11056

Peterson Wi, Bond NA, Robert M (2016) The Blob (Part 3): going, going, gone? PICES Press 24:46-48

Piatt JF, Anderson PJ (1996) Response of common murres to the Exxon Valdez oil spill and long term changes in the Gulf of Alaska marine ecosystem. In: Rice SD, Spies RB, Wolfe DA, Wright BA (eds) Exxon Valdez Oil Spill Symposium Proceedings. Symposium 18. American Fisheries Society, Bethesda, MD, p 720-737

Piatt JF, Arimitsu ML, Sydeman WJ, Thompson SA and others (2018) Biogeography of pelagic food webs in the North Pacific. Fish Oceanogr 27:366-380

Purcell JE, Sturdevant MV (2001) Prey selection and dietary overlap among zooplanktivorous jellyfish and juvenile fishes in Prince William Sound, Alaska. Mar Ecol Prog Ser 210:67-83

Quinn T, Schneider D (1991) Respiration of the teleost fish Ammodytes hexapterus in relation to its burrowing behavior. Comp Biochem Physiol 98:71-75

Robards MD, Anthony JA, Rose GA, Piatt JF (1999a) Changes in proximate composition and somatic energy content for Pacific sand lance (Ammodytes hexapterus) from Kachemak Bay, Alaska relative to maturity and season. J Exp Mar Biol Ecol 242:245-258

Robards MD, Piatt JF, Rose GA (1999b) Maturation, fecun- dity, and intertidal spawning of Pacific sand lance in the northern Gulf of Alaska. J Fish Biol 54:1050-1068

Robards MD, Willson MF, Armstrong RH, Piatt JF (1999c) Sand lance: a review of biology and predator relations and annotated bibliography. Res Pap PNW-RP-521. US Department of Agriculture, Forestry Service, Pacific Northwest Research Station, Portland, OR

Robards MD, Rose GA, Piatt JF (2002) Growth and abundance of Pacific sand lance, Ammodytes hexapterus, under differing oceanographic regimes. Environ Biol Fishes 64:429-441

Sturdevant MV, Wertheimer AC, Lum J (1996) Diets of juvenile pink and chum salmon in oiled and non-oiled nearshore habitats in Prince William Sound, 1989 and 1990. Am Fish Soc Symp 18:578-592

Sydeman WJ, Piatt JF, Thompson SA, García Reyes M and others (2017) Puffins reveal contrasting relationships between forage fish and ocean climate in the North Pacific. Fish Oceanogr 26:379-395

* Tomiyama M, Yanagibashi S (2004) Effect of temperature, age class, and growth on induction of aestivation in Japanese sandeel (Ammodytes personatus) in Ise Bay, central Japan. Fish Oceanogr 13:81-90

*Van Pelt T, Piatt J, Lance BK, Roby DD (1997) Proximate composition and energy density of some North Pacific forage fishes. Comp Biochem Physiol Part A Physiol 118: 1393-1398

* von Biela VR, Kruse GH, Mueter FJ, Black BA, Douglas DC, Helser TE, Zimmerman CE (2015) Evidence of bottom-up limitations in nearshore marine systems based on otolith proxies of fish growth. Mar Biol 162:1019-1031

*Walsh JE, Thoman RL, Bhatt US, Bieniek PA and others (2018) The high latitude marine heat wave of 2016 and its impact on Alaska. Bull Am Meterol Soc 99:S39-S43

* Wanless S, Harris MP, Redman P, Speakman JR (2005) Low energy values of fish as a probable cause of a major seabird breeding failure in the North Sea. Mar Ecol Prog Ser 294:1-8

*Wanless S, Harris MP, Newell MA, Speakman JR, Daunt F (2018) Community-wide decline in the occurrence of lesser sandeels Ammodytes marinus in seabird chick diets at a North Sea colony. Mar Ecol Prog Ser 600: 193-206

*Weingartner T, Coyle K, Finney B, Hopcroft R and others (2002) The Northeast Pacific GLOBEC Program: coastal Gulf of Alaska. Oceanography 15:48-63

*Weitkamp LA, Sturdevant MV (2008) Food habits and marine survival of juvenile chinook and coho salmon from marine waters of Southeast Alaska. Fish Oceanogr 17: 380-395

Yang MS, Nelson MW (1999) Food habits of the commercially important groundfishes in the Gulf of Alaska in 1990, 1993, and 1996. Tech Memo AFSC 112. USDC, NOAA, NMFS. https://www.afsc.noaa.gov/refm/reem/ doc/techmemoafsc112.pdf

Yang MS, Dodd K, Hibpshman R, Whitehouse A (2006) Food habits of groundfishes in the Gulf of Alaska in 1999 and 2001. NOAA Tech Memo NMFS-AFSC-164. https:// www.afsc.noaa.gov/Publications/AFSC-TM/NOAA-TMAFSC-164.pdf

Zador S, Yasumiishi EM (2017) Ecosystem considerations 2017. Stock assessment and fishery evaluation report for the Gulf of Alaska. North Pacific Fishery Management Council, Anchorage, AK 


\section{Appendix.}

Table A1. Mean monthly temperatures $\left({ }^{\circ} \mathrm{C}_{i}\right.$ 2003-2016) used to calculate monthly anomalies presented in Fig. 3 and absolute temperature values for the years of sample collections

\begin{tabular}{|lcccccc|}
\hline Month & Mean & 2012 & 2013 & 2014 & 2015 & 2016 \\
\hline January & 4.51 & 3.81 & 3.91 & 4.84 & 6.09 & 5.23 \\
February & 3.84 & 3.18 & 3.03 & 3.49 & 5.39 & 5.12 \\
March & 3.69 & 2.61 & 2.95 & 3.38 & 5.01 & 5.05 \\
April & 4.68 & 4.73 & 3.89 & 5.13 & 5.46 & 6.15 \\
May & 8.11 & 6.78 & 6.30 & 9.45 & 9.64 & 9.29 \\
June & 11.7 & 10.2 & 12.7 & 11.7 & 11.7 & 13.1 \\
July & 13.8 & 11.5 & 14.9 & 14.1 & 14.3 & 15.3 \\
August & 13.6 & 12.7 & 13.9 & 13.8 & 15.8 & 13.8 \\
September & 11.7 & 10.7 & 11.8 & 12.1 & 11.9 & 12.4 \\
October & 8.94 & 7.62 & 9.37 & 9.75 & 9.31 & 9.30 \\
November & 6.95 & 6.00 & 7.40 & 8.16 & 7.57 & 7.45 \\
December & 5.55 & 4.95 & 5.39 & 6.98 & 5.99 & 6.46 \\
\hline
\end{tabular}

Editorial responsibility: Stylianos Somarakis, Heraklion, Greece
Submitted: September 18, 2018; Accepted: February 11, 2019 Proofs received from author(s): March 13, 2019 